\title{
A IDENTIDADE CULTURAL NA PÓS-MODERNIDADE ${ }^{1}$
}

\author{
Rafael Zilio Fernandes ${ }^{2}$
}

O livro de Stuart Hall procura realizar uma análise da identidade na pós-modernidade, ou "modernidade tardia", como cita o autor. Para isso, são debatidos temas como a crise de identidade do sujeito, a descentração do sujeito, a questão das identidades nacionais e a influência da globalização no hibridismo e reforço das identidades, fazendo alusão à resistência do fundamentalismo religioso.

As velhas identidades criadas a partir do renascimento cultural e do iluminismo europeu estão em declínio num mundo pautado pela compressão espaço-tempo. Nisso, temos uma crise de identidade que fragmenta o indivíduo moderno. O homem da sociedade moderna era possuidor de um lugar bem determinado socialmente e culturalmente. No entanto, mudanças estruturais estão trazendo questionamentos quanto a identidades culturais de classe, raça, nacionalidade, sexo e etnia. Isso faz com que a ancoragem estável dos indivíduos no mundo social esteja abalada. A análise de Stuart Hall parte da premissa de que as identidades modernas estão sendo descentradas.

No primeiro capítulo o autor resgata três concepções de identidade ao longo da história dos últimos séculos. A primeira é o sujeito do Iluminismo. Tal sujeito estava baseado numa concepção de pessoa humana como um indivíduo totalmente centrado, unificado, dotado das capacidades de razão, de consciência e de ação. Essa era uma concepção bastante individualista do sujeito. A segunda concepção de identidade é o sujeito sociológico. Nessa concepção estava traduzida a crescente complexidade do mundo moderno. A identidade era construída na interação entre o indivíduo e a sociedade. Na terceira concepção de identidade está o sujeito pós-moderno. Aqui está o foco da análise do livro. O sujeito possuidor de uma identidade estável está se fragmentando e sendo composto por várias identidades. Esse sujeito não tem uma identidade fixa, essencial ou permanente.

As principais mudanças na forma pela qual o sujeito e a identidade são conceituadas estão no capítulo 2. As transformações associadas à modernidade libertaram o indivíduo de

\footnotetext{
${ }^{1}$ Resenha desenvolvida como forma de avaliação para a disciplina de Geografia Cultural, ministrada pela professora Rosa Maria Vieira Medeiros no primeiro semestre de 2007, na Universidade Federal do Rio Grande do Sul.

${ }_{2}^{2}$ Graduando em Geografia (Licenciatura) pela Universidade Federal do Rio Grande do Sul. E-mail: geografodafronteira@yahoo.com.br.
} 
seus apoios estáveis nas tradições e estruturas. Antes da modernidade acreditava-se que o status e a posição de uma pessoa na sociedade eram divinamente estabelecidos, e isso imperava sobre qualquer sentimento de que a pessoa fosse um indivíduo soberano. $\mathrm{O}$ nascimento desse indivíduo soberano se dá no século XVI com o Renascimento e no século XVIII com o Iluminismo. Então, o homem racional e científico passou a ser o norteador dessa nova identidade. Hall utiliza-se de Descartes e Locke para reforçar as idéias do homem centrado da modernidade.

Na modernidade tardia (segunda metade do século XX), por conseguinte, o sujeito foi sendo deslocado de sua identidade e o indivíduo foi sendo descentrado. $\mathrm{O}$ autor considera cinco grandes avanços na teoria social e nas ciências humanas cujo maior argumento foi o descentramento do sujeito cartesiano. O primeiro grande avanço está nas tradições do pensamento marxista que foram redescobertos e reinterpretados na década de 1960. O segundo foi a descoberta do inconsciente por Freud. Tal teoria explica que a identidade é algo formado, ao longo do tempo, através de processos inconscientes, e não algo inato, existente na consciência do momento do nascimento. $\mathrm{O}$ terceiro avanço teórico associa-se com o trabalho de Ferdinand de Saussure. Esse autor argumentava que nós não somos os autores das afirmações que fazemos ou dos significados que expressamos na língua. $O$ quarto descentramento da identidade e do sujeito está no trabalho de Michel Foucault, que focaliza os regimes disciplinares do moderno poder administrativo. Por fim, o quinto descentramento é o movimento feminista. Esse movimento questionou a distinção entre público e privado, contestou politicamente a vida social, politizou a subjetividade, a identidade o processo de identificação.

Stuart Hall também analisa a questão das culturas nacionais e da identidade de nação, e como o sujeito fragmentado é colocado em termos de suas identidades culturais. Antes, na modernidade, a identidade nacional consistia em uma homogeneização necessária da cultura e uma unificadora do pensamento cultural o indivíduos. No entanto, o que observamos na pósmodernidade é um grande avanço do hibridismo cultural dentro de um mesmo Estado-nação. Confundem-se diferentes culturas advindas dos mais variados lugares do mundo num mesmo local, decorrente das migrações e da difusão das comunicações. Hall considera uma cultura nacional como um discurso, um modo de construir sentidos que influencia e organiza tanto nossas ações quanto a concepção que temos de nós mesmos. Mas quando o conceito de raça é usado de uma forma discursiva mais ampla, as nações modernas não são determinadas por ela, devido ao fato de a maioria das nações serem compostas por sangue essencialmente misto. 
A globalização é tratada por Stuart Hall como sendo provocadora de uma sobreposição das identidades nacionais por outras mais particularistas, de identificação cultural. O processo de globalização está deslocando as identidades nacionais. Esse processo implica num distanciamento da idéia sociológica clássica da sociedade como um sistema bem delimitado. A compressão espaço-tempo de uma sociedade "em rede" cria ferramentas para um choque ou uma hibridização de diferentes identidades formadas ao longo do planeta. Assim, se sente que o mundo é menor e as distâncias são mais curtas, que os eventos em um determinado lugar têm um impacto imediato sobre pessoas e lugares distantes. Criam-se, então, laços identitários "acima" ou "abaixo" da escala do Estado-nação.

Porém, Stuart Hall questiona se as identidades nacionais estão sendo homogeneizadas. Vindo ao encontro desse argumento, tem-se que ao lado da tendência à homogeneização global há também uma fascinação com a diferença e com a mercantilização da etnia e da alteridade. Juntamente com o impacto do "global" temos um novo interesse pelo "local", constituindo uma nova articulação entre essas duas escalas. Mas a globalização é desigualmente distribuída ao redor do globo. O fluxo de globalização é desequilibrado, continuam a existir relações desiguais de poder cultural entre o "ocidente" e o "resto". Embora usa-se esse termo, a globalização é um fenômeno essencialmente ocidental.

O fenômeno da migração é algo que expressa muito bem a relativização das identidades culturais. Destaca-se aí a grande massa de imigrantes localizados em países europeus e nos Estados Unidos tidos antes como "puros" e que agora são possuidores de expressivas diferenças étnicas no interior de seus Estados-nações. A globalização, então, tem o efeito de contestar e deslocar as identidades centradas e fechadas de uma cultura nacional.

Contudo, encontramos hoje uma reação à ação globalizante, principalmente em Estados islâmicos fundamentalistas. Podem ser considerados casos de reconstrução de identidades purificadas, para se restaurar a coesão da nação - uma nação unificada em termos étnicos e religiosos. Segundo preceitos tanto liberais quanto marxistas, os apegos ao local e ao particular desapareceriam com a modernidade. Porém, o que vemos é uma forte inversão dessa lógica com o reforço de regionalismos e tentativas de afirmação identitária em muitos locais, numa relação nova com o global. Hall conclui que todos esses processos podem acabar sendo parte do lento e desigual, mas continuado, descentramento do Ocidente.

Então, podemos afirmar que o livro de Stuart hall fornece bons subsídios para aqueles que desejam entender a questão da identidade no atual mundo pós-moderno em que vivemos. Porém a visão de muitos aspectos globais é demasiadamente eurocêntrica, não levando em consideração aspectos importantes da identidade pós-moderna no mundo subdesenvolvido. 


\section{Referência bibliográfica}

HALL, Stuart. A identidade cultural na pós-modernidade. $7^{\mathrm{a}}$ ed. Rio de Janeiro: DP\&A, 2002. 